\title{
Supinidine Viridiflorates from the Roots of Chromolaena pulchella
}

\author{
Mario A. Gómez-Hurtado ${ }^{a, b}$, J. Martín Torres-Valencia ${ }^{a}{ }^{a} *$, Rosa E. del Río ${ }^{b}$, Gabriela Rodríguez-García ${ }^{b}$, \\ Virginia Motilva $^{\mathrm{c}}$, Sofía García-Mauriño ${ }^{\mathrm{d}}$, Carlos M. Cerda-García-Rojas ${ }^{\mathrm{e}}$ and Pedro Joseph-Nathan ${ }^{\mathrm{e}}$ \\ a'́rea Académica de Química, Universidad Autónoma del Estado de Hidalgo, Km 4.5 Carretera Pachuca- \\ Tulancingo, Mineral de la Reforma, Hidalgo 42184, Mexico \\ binstituto de Investigaciones Químico-Biológicas, Universidad Michoacana de San Nicolás de Hidalgo, \\ Apartado 137, Morelia, Michoacán 58000, Mexico \\ ${ }^{\mathrm{c}}$ Facultad de Farmacia, Universidad de Sevilla, Profesor García González No. 2, Sevilla 41012, Spain \\ ${ }^{\mathrm{d}}$ Facultad de Biología, Universidad de Sevilla, Profesor García González No. 2, Sevilla 41012, Spain \\ ${ }^{\mathrm{e}}$ Departamento de Química, Centro de Investigación y de Estudios Avanzados del Instituto Politécnico Nacional, \\ Apartado 14-740, México, D. F., 07000 Mexico
}

jmartin@uaeh.edu.mx

Received: September 13 ${ }^{\text {th }}, 2013$; Accepted: September $18^{\text {th }}, 2013$

The alkaloid extract from the roots of Chromolaena pulchella provided two new pyrrolizidine alkaloids, elucidated as (-)-supinidine triviridiflorate (1) and $(-)$-supinidine diviridiflorate (2) based on their physical and spectroscopic properties. Their absolute configuration was determined by chemical correlation with (-)-supinidine (3) and (+)-viridifloric acid (4)

Keywords: Chromolaena pulchella, Asteraceae, Pyrrolizidine alkaloids, Absolute configuration, NMR spectroscopy.

Pyrrolizidine alkaloids (PAs), although widely distributed, are characteristic of certain genera of the Boraginaceae, Leguminosae, and Asteraceae/Compositae families [1]. Many PAs are known to produce hepatic toxicity and there are several records of livestock poisoning [1a,b]. Chemical studies of some Chromolaena species (Asteraceae) showed the presence of this class of natural molecules. Thus $\mathrm{N}$-oxides of 7 -angeloylretronecine, intermidine, licopsamine, echinatine, 3 '-acetylrinderine, and supinine have been identified in C. odorata [1c]. The present work describes the isolation of the new PAs supinidine triviridiflorate (1) and supinidine diviridiflorate (2) (Figure 1) from the crude alkaloid extract of the roots of C. pulchella, for which we recently reported the isolation of labdanes and ent-clerodanes from the aerial parts [1d].

Compound 1, a pale yellow oil, showed a $[\mathrm{M}+1]^{+}$ion at $\mathrm{m} / \mathrm{z}$ 572.3427 in its HRESI/APCI mass spectrum revealing the molecular formula $\mathrm{C}_{29} \mathrm{H}_{49} \mathrm{NO}_{10}+\mathrm{H}$ (calcd $m / z$ 572.3435). The ${ }^{1} \mathrm{H}$ NMR chemical shift values of the alkaloid moiety were in agreement with those for a supinidine type pyrrolizidine ring system [2]. The complete ${ }^{1} \mathrm{H}$ and ${ }^{13} \mathrm{C}$ data, shown in Table 1 , gave characteristic signals for a 1,2-unsaturated pyrrolizidine alkaloid with a necic acid esterified at C-9. The ${ }^{1} \mathrm{H}$ NMR spectrum of 1 showed signals assignable to a vinylic proton at $\delta_{\mathrm{H}} 5.71(\mathrm{H}-2)$ and an $\mathrm{AB}$ system $(J=13.6 \mathrm{~Hz})$ at $\delta_{\mathrm{H}} 4.72$ and 4.60 due to protons of the C-9 hydroxymethylene group, whereas the signal for the hydrogen atom attached to bridgehead C-8 was observed at $\delta_{\mathrm{H}} 4.15$. The signals for the methylene groups at $\mathrm{C}-3$ and $\mathrm{C}-5$, bearing the nitrogen atom, were observed at $\delta_{\mathrm{H}} 3.91$ and 3.37 , and at 3.11 and 2.53 , respectively. Moreover, signals for a trimeric $\alpha$-isopropyl- $\alpha, \beta$ dihydroxybutyric acid residue were observed as quartets at $\delta_{\mathrm{H}} 5.35$ $(J=6.2 \mathrm{~Hz}, \mathrm{H}-13), 4.98(J=6.6 \mathrm{~Hz}, \mathrm{H}-20)$, and $4.09(J=6.6 \mathrm{~Hz}$, $\mathrm{H}-27)$ showing strong correlation in the COSY spectrum with the doublets at $\delta_{\mathrm{H}} 1.39(\mathrm{Me}-14), 1.22(\mathrm{Me}-21)$, and 1.21 (Me-28), respectively. The ${ }^{13} \mathrm{C}$ and APT NMR spectra showed signals for three carbonyl carbon atoms at $\delta_{\mathrm{C}} 174.0(\mathrm{C}-18), 173.6(\mathrm{C}-25)$, and
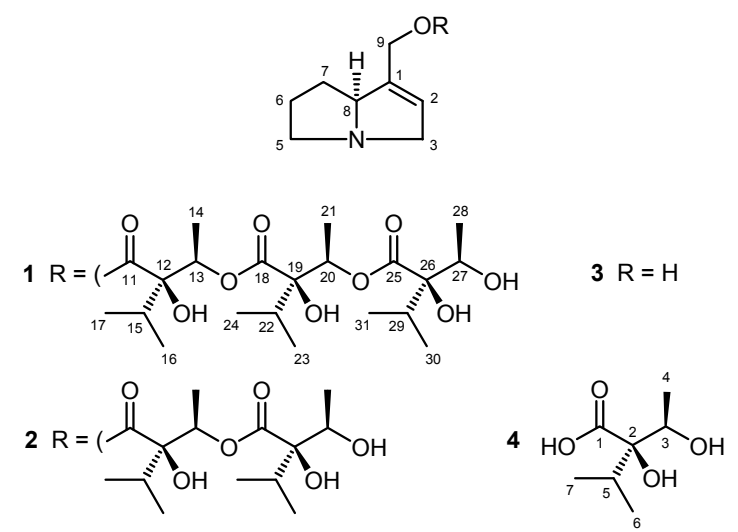

173.3 (C-11), for two vinylic carbons at 136.9 (C-1) and 126.1 (C-2), for three quaternary carbons bearing oxygen atoms at 82.6 (C-26), 81.7 (C-12), and 80.3 (C-19), for seven methine carbons, three of them bearing oxygen atoms at $76.4(\mathrm{C}-13), 71.5(\mathrm{C}-20)$ and 69.4 (C-27), one bearing the nitrogen atom at $71.5(\mathrm{C}-8)$, and three owing to the isopropyl groups at 33.8 (C-15), 32.7 (C-29) and 30.9 (C-22), for five methylene carbons, one of them bearing an oxygen atom at $61.9(\mathrm{C}-9)$, two bearing the nitrogen atom at $61.6(\mathrm{C}-3)$ and 56.6 (C-5), and two at 30.2 (C-7) and 25.7 (C-6), and for six methyl groups owing to three isopropyl groups at 17.3, 17.0, 16.9, 16.8, 16.6 and 15.3 . Esterification at the $\mathrm{C}-9$ position was confirmed by the $\mathrm{HMBC}$ correlation between $\mathrm{H}_{2}-9$ and the carbonyl group $\mathrm{C}-11$, while the individual assignments for the three acid residues were supported from $\mathrm{HMBC}$ correlations of $\mathrm{H}-13$ with $\mathrm{C}-11$ and $\mathrm{C}-12$, of $\mathrm{H}-20$ with $\mathrm{C}-18$ and $\mathrm{C}-19$, and of $\mathrm{H}-27$ with $\mathrm{C}-25$ and C-26.

Compound 2 exhibited in its HRESI/APCI mass spectrum a $[\mathrm{M}+1]^{+}$ion at $\mathrm{m} / \mathrm{z} 428.2646$ in agreement with the molecular formula $\mathrm{C}_{22} \mathrm{H}_{37} \mathrm{NO}_{7}+\mathrm{H}$ (calcd $m / z$ 428.2648). The complete ${ }^{1} \mathrm{H}$ and ${ }^{13} \mathrm{C}$ data shown in Table 1 demonstrated high structural similarities 
Table 1: ${ }^{13} \mathrm{C}$ and ${ }^{1} \mathrm{H}$ NMR data for 1 and $2\left(100\right.$ and $\left.400 \mathrm{MHz}, \mathrm{CDCl}_{3}\right) .{ }^{\mathrm{a}}$

\begin{tabular}{|c|c|c|c|c|}
\hline \multirow[b]{2}{*}{ Position } & \multicolumn{2}{|r|}{1} & \multicolumn{2}{|r|}{2} \\
\hline & $\delta_{\mathrm{C}}$, mult. & $\delta_{\mathrm{H}}$, mult. $(J$ in Hz) & $\delta_{\mathrm{C}}$, mult. & $\delta_{\mathrm{H}}$, mult. $(J$ in Hz$)$ \\
\hline 1 & $136.9, \mathrm{C}$ & & $136.9, \mathrm{C}$ & \\
\hline 2 & $126.1, \mathrm{CH}$ & $5.71, \mathrm{br} \mathrm{s}$ & $125.7, \mathrm{CH}$ & $5.73, \mathrm{br} \mathrm{s}$ \\
\hline 3 & $61.6, \mathrm{CH}_{2}$ & 3.91 , br d (15.8) & $61.2, \mathrm{CH}_{2}$ & 3.95 , br d (15.8) \\
\hline $3^{\prime}$ & & $3.37, \mathrm{dd}(15.8,4.4)$ & & 3.40, br d $(15.8)$ \\
\hline 5 & $56.6, \mathrm{CH}_{2}$ & $3.11, \mathrm{dt}(9.9,5.5)$ & $56.6, \mathrm{CH}_{2}$ & $3.18, \mathrm{dt}(10.0,5.1)$ \\
\hline $5^{\prime}$ & & $2.53, \mathrm{dt}(9.9,7.0)$ & & $2.54, \mathrm{dt}(10.0,7.0$ \\
\hline 6 & $25.7, \mathrm{CH}_{2}$ & $1.80, \mathrm{~m}$ & 25.7, $\mathrm{CH}_{2}$ & $1.81, \mathrm{~m}$ \\
\hline 7 & $30.2, \mathrm{CH}_{2}$ & $1.98, \mathrm{~m}$ & $29.9, \mathrm{CH}_{2}$ & $2.04, \mathrm{~m}$ \\
\hline $7^{\prime}$ & & $1.50, \mathrm{~m}$ & & $1.54, \mathrm{~m}$ \\
\hline 8 & $71.5, \mathrm{CH}$ & $4.15, \mathrm{br} \mathrm{m}$ & $71.5, \mathrm{CH}$ & 4.25 , br m \\
\hline 9 & $61.9, \mathrm{CH}_{2}$ & 4.72, br d (13.6) & $62.2, \mathrm{CH}_{2}$ & 4.80, br d (13.5) \\
\hline $9^{\prime}$ & & 4.60, br d (13.6) & & 4.74, br d (13.5) \\
\hline 11 & 173.3, C & & 174.0, C & \\
\hline 12 & $81.7, \mathrm{C}$ & & $81.2, \mathrm{C}$ & \\
\hline 13 & $76.4, \mathrm{CH}$ & $5.35, \mathrm{q}(6.2)$ & $73.9, \mathrm{CH}$ & $5.26, \mathrm{q}(6.2)$ \\
\hline 14 & $13.1, \mathrm{CH}_{3}$ & $1.39, \mathrm{~d}(6.2)$ & $13.9, \mathrm{CH}_{3}$ & $1.32, \mathrm{~d}(6.2)$ \\
\hline 15 & $33.8, \mathrm{CH}$ & $1.98, \operatorname{sept}(7.0)$ & $32.6, \mathrm{CH}$ & 2.09, sept $(7.0)$ \\
\hline 16 & $17.0, \mathrm{CH}_{3}$ & $1.05, \mathrm{~d}(7.0)$ & $16.4, \mathrm{CH}_{3}$ & $0.94, \mathrm{~d}(7.0)$ \\
\hline 17 & $17.3, \mathrm{CH}_{3}$ & $0.96, \mathrm{~d}(7.0)$ & $17.1, \mathrm{CH}_{3}$ & $0.96, \mathrm{~d}(7.0)$ \\
\hline 18 & 174.0, C & & 174.3, C & \\
\hline 19 & $80.3, \mathrm{C}$ & & $82.4, \mathrm{C}$ & \\
\hline 20 & $71.5, \mathrm{CH}$ & $4.98, \mathrm{q}(6.6)$ & $69.2, \mathrm{CH}$ & $3.95, \mathrm{q}(6.6)$ \\
\hline 21 & 14.6, $\mathrm{CH}_{3}$ & $1.22, \mathrm{~d}(6.6)$ & $17.5, \mathrm{CH}_{3}$ & $1.17, \mathrm{~d}(6.6)$ \\
\hline 22 & $30.9, \mathrm{CH}$ & 2.09, sept $(7.0)$ & $32.3, \mathrm{CH}$ & 2.08, sept $(7.0)$ \\
\hline 23 & $15.3, \mathrm{CH}_{3}$ & $0.86, \mathrm{~d}(7.0)$ & $16.4, \mathrm{CH}_{3}$ & $0.92, \mathrm{~d}(7.0)$ \\
\hline 24 & $16.9, \mathrm{CH}_{3}$ & $0.74, \mathrm{~d}(7.0)$ & $16.9, \mathrm{CH}_{3}$ & $0.87, \mathrm{~d}(7.0)$ \\
\hline 25 & 173.6, C & & & \\
\hline 26 & $82.6, \mathrm{C}$ & & & \\
\hline 27 & $69.4, \mathrm{CH}$ & $4.09, \mathrm{q},(6.6)$ & & \\
\hline 28 & $17.2, \mathrm{CH}_{3}$ & $1.21, \mathrm{~d}(6.6)$ & & \\
\hline 29 & $32.7, \mathrm{CH}$ & 2.09, sept $(7.0)$ & & \\
\hline 30 & $16.8, \mathrm{CH}_{3}$ & $0.94, \mathrm{~d}(7.0)$ & & \\
\hline 31 & $16.6, \mathrm{CH}_{3}$ & $1.00, \mathrm{~d}(7.0)$ & & \\
\hline
\end{tabular}

with the aforementioned PA $\mathbf{1}$, implying that compounds $\mathbf{1}$ and $\mathbf{2}$ belong to the same class of alkaloids. Compound $\mathbf{2}$ differed from $\mathbf{1}$ in the absence of the third $\alpha$-isopropyl- $\alpha, \beta$-dihydroxybutyric acid residue, since in the ${ }^{1} \mathrm{H}$ NMR spectrum only two methine signals for protons bearing oxygen atoms were observed at $\delta_{\mathrm{H}} 5.26(\mathrm{q}, J=6.2$ $\mathrm{Hz}, \mathrm{H}-13$ ), and 3.95 (q, $J=6.6 \mathrm{~Hz}, \mathrm{H}-20$ ), whereas in the ${ }^{13} \mathrm{C} \mathrm{NMR}$ spectrum only two carbonyl groups signals were observed at $\delta_{\mathrm{C}} 174.0(\mathrm{C}-11)$, and $174.3(\mathrm{C}-18)$. As in the case of compound $\mathbf{1}$, 2D NMR spectroscopy was employed to completely assign the ${ }^{13} \mathrm{C}$ and ${ }^{1} \mathrm{H}$ spectra. Alkaline hydrolysis of a mixture of compounds $\mathbf{1}$ and 2 gave the necine base (-)-supinidine (3) [2,3a] and the necic acid residue (+)-viridifloric acid (4) [3b].

\section{Experimental}

General: Optical rotation, Perkin-Elmer 341 polarimeter; IR, Perkin-Elmer 16F PC IR-FT spectrophotometer using thin films of compounds deposited on a CsI crystal; Low-resolution MS, either Agilent 1100 LC/MSD or Varian Saturn 2000 spectrometers; HRMS, Agilent LCTOF instrument; NMR, JEOL Eclipse 400 spectrometer; CC, Merck silica gel 40; TLC, silica gel 60 precoated glass plates.

Plant material: Specimens of C. pulchella (H.B.K.) R.M. King \& H. Rob. (Asteraceae) were collected near km 61 of Morelia-Zacapu federal road 15, in the municipality of Constitución, State of Michoacán, México, during October 2005. A specimen (No. 192522) is deposited at the Herbarium of Instituto de Ecología A.
C., Centro Regional del Bajío, Pátzcuaro, Michoacán, Mexico, where Prof. Jerzy Rzedowski kindly identified the plant material.

Extraction and isolation: Air-dried and powdered roots of $C$. pulchella $(870 \mathrm{~g})$ were extracted with $\mathrm{MeOH}(3.5 \mathrm{~L})$ under reflux for $6 \mathrm{~h}$. Filtration and evaporation of the extract afforded a yellow viscous oil (38.6 g) which gave a positive Dragendorff test. To this product aq. $\mathrm{HCl} 2 \%(300 \mathrm{~mL})$ and zinc powder $(40 \mathrm{~g})$ were gradually added under stirring for $12 \mathrm{~h}$. The acidic aqueous solution was treated with aq. $\mathrm{KOH} 5 \%$ to obtain a phase with $\mathrm{pH} 10$ and then extracted with $\mathrm{CHCl}_{3}(3 \times 200 \mathrm{~mL})$, dried over anhydrous $\mathrm{Na}_{2} \mathrm{SO}_{4}$, filtered, and evaporated to provide $2.6 \mathrm{~g}$ of residue. A portion of this $(876 \mathrm{mg}$ ) was subjected to chromatography on silica gel 60 (20 g) using $\mathrm{CHCl}_{3}-\mathrm{MeOH}$-diethylamine (98:2:1, 96:4:1, 90:10:1, and 80:20:1). Fractions of $100 \mathrm{~mL}$ of each polarity were collected, monitored by TLC, and analyzed by ${ }^{1} \mathrm{H}$ NMR spectroscopy. The resulting material from each fraction was labelled as A (138 mg), B (354 mg), C (112 mg) and D (116 mg). From fractions A, C, and D fatty materials were isolated. Separation of fraction $\mathrm{B}(178 \mathrm{mg})$ by means of preparative TLC using $\mathrm{CHCl}_{3}-$ $\mathrm{MeOH}(9: 1)$ as the mobile phase gave pure 1 (45 $\mathrm{mg}, R_{f} 0.5$ ). Another portion of fraction B (138 mg) was purified by TLC $\left(\mathrm{CHCl}_{3}-\mathrm{MeOH}-\mathrm{H}_{2} \mathrm{O}, 200: 50: 7\right)$ affording 2 (20 mg, $\left.R_{f} 0.2\right)$.

\section{Supinidine triviridiflorate (1)}

Pale yellow oil; $[\alpha]_{\mathrm{D}}^{20}:-1.5\left(\right.$ c $\left.3.5, \mathrm{CHCl}_{3}\right)$

IR (film): 3518, 2972, 2937, 2878, 1725, 1454, $1386 \mathrm{~cm}^{-1}$.

${ }^{1} \mathrm{H}$ and ${ }^{13} \mathrm{C}$ NMR: Table 1.

MS (EI, $70 \mathrm{eV}): m / z(\%) 572[\mathrm{M}+1]^{+}$(40), 428 (2), 410 (4), 284

(3), 266 (19), 140 (19), 122 (100), 110 (10), 107 (6), 94 (25), 70

(38); HRESI/APCIMS: $m / z[\mathrm{M}+1]^{+}$calcd for $\mathrm{C}_{29} \mathrm{H}_{49} \mathrm{NO}_{10}+\mathrm{H}$ : 572.3435; found: 572.3427 .

\section{Supinidine diviridiflorate (2)}

Pale yellow oil; $[\alpha]_{\mathrm{D}}{ }^{20}:-8.2\left(\right.$ c $\left.2.0, \mathrm{CHCl}_{3}\right)$.

IR (film): 3024, 2970, 2945, 1727, 1456, $1389 \mathrm{~cm}^{-1}$.

${ }^{1} \mathrm{H}$ and ${ }^{13} \mathrm{C}$ NMR: Table 1.

MS (EI, $70 \mathrm{eV}): m / z(\%)=428[\mathrm{M}+1]^{+}(2), 396(2), 382(2), 284$ (28), 224 (6), 140 (19), 122 (100); HRESI/APCIMS: $m / z[\mathrm{M}+1]^{+}$ calcd for $\mathrm{C}_{22} \mathrm{H}_{37} \mathrm{NO}_{7}+\mathrm{H}$ : 428.2648 ; found: 428.2646 .

Hydrolysis of compounds 1 and 2: A mixture of 1 and 2 (40 mg) in $\mathrm{MeOH}(3 \mathrm{~mL})$ was treated with $\mathrm{NaOH}(24 \mathrm{mg})$ in $\mathrm{H}_{2} \mathrm{O}(0.25 \mathrm{~mL})$ and heated to reflux for $15 \mathrm{~min}$ in a micro-wave system working at $100 \mathrm{~W}$. The mixture was treated with $\mathrm{H}_{2} \mathrm{O}(10 \mathrm{~mL})$ and extracted with $\mathrm{CH}_{2} \mathrm{Cl}_{2}(2 \times 10 \mathrm{~mL})$ to give (-)-supinidine (3) $(3.5 \mathrm{mg})$ as a yellow oil, which showed $[\alpha]_{\mathrm{D}}-9.1(c 0.16, \mathrm{EtOH})$ lit. $[\alpha]_{\mathrm{D}}-10.4(c$ $2.64, \mathrm{EtOH})[3 \mathrm{a}]$. The aq. phase was acidified with $2 \% \mathrm{HCl}$ and extracted with $\mathrm{CH}_{2} \mathrm{Cl}_{2}(2 \times 10 \mathrm{~mL})$ to give (+)-viridifloric acid (4) (24 mg) [3b,4].

Acknowledgments - Partial financial support from Conacyt, Mexico (grant No. U2-80555), from ICYTDF (grant No. 337/2010), and PROMEP-UMSNH (grant No. 332) is acknowledged.

\section{References}

[1] (a) Hartmann T. (1999) Chemical ecology of pyrrolizidine alkaloids. Planta, 207, 483-495; (b) Chen T, Mei N, Fu PP. (2009) Genotoxicity of pyrrolizidine alkaloids. Journal of Applied Toxicology, 30, 183-196; (c) Biller A, Boppré M, Witte L, Hartmann T. (1994) Pyrrolizidine alkaloids in Chromolaena odorata. Chemical and chemoecological aspects. Phytochemistry, 35, 615-619; (d) Gómez-Hurtado MA, Torres-Valencia JM, Manríquez-Torres J, del Río RE, Motilva V, García-Mauriño S, Ávila J, Talero E, Cerda-García-Rojas CM, Joseph-Nathan P. (2011) Absolute configuration of labdanes and ent-clerodanes from Chromolaena pulchella by vibrational circular dichroism. Phytochemistry, 72, 409-414.

[2] Logie CG, Grue MR, Liddell JR. (1994) Proton NMR spectroscopy of pyrrolizidine alkaloids. Phytochemistry, 37, 43-109.

[3] (a) Gruszecka-Kowalik E, Zalkow LH. (1990) Free-radical reactions of retronecine and heliotridine derivatives. The synthesis of (-)-supinidine. The Journal of Organic Chemistry, 55, 3398-3403; (b) Stritzke K, Schulz S, Nishida R. (2002) Absolute configuration and synthesis of $\beta$ - and $\delta$-lactones present in the pheromone system of the giant white butterfly Idea leuconoe. European Journal of Organic Chemistry, 388-392.

[4] Schulz S, Nishida R. (1996) The pheromone system of the male danaine butterfly, Idea leuconoe. Bioorganic \& Medicinal Chemistry, 4, 341-349. 